\title{
EXCAVATIONS IN BOEOTIA.
}

THE excavation of the ancient cemetery at Rhitsona in Boeotia was continued for a few weeks this spring by Mr. P. N. Ure, with the help of grants from the Cambridge Craven Fund and the British School at Athens. Seven more rich 6 th century graves were excavated like those opened by Professor Burrows last autumn (see Class. Rev. Feb. 1908, p. 29). Each grave contained large quantities of Boeotian pottery and figurines, aryballi, cothons, coarse black figure ware and plain black glaze ware. Most of them contained also one or two diminutive 'Rhodian' faience amphorae and a few objects of special interest, e.g. a well preserved silenus figurine, a late archaic equestrian figurine, a bronze tripod with remains of an iron bowl, remains of a silver phiale, and one or two incised inscriptions on the feet of vases. Each grave contained the remains of a single skeleton. Occasional finds in the series of such objects as the horseman just referred to and a lecythus with a toilet scene in outline on a very pale yellow ground confirm the view that the graves, in spite of the primitive character of much of their contents, cannot date much before 500 B.c. These early graves were $3 \mathrm{~m}$. deep and had no stone slabs or covering. A number of $\pi i \theta$ os burials of about the same date were also found. They contained generally nothing but a few aryballi and possibly one or two animal figurines or rough black figure lecythi.

Besides these, a series of Hellenistic graves of stone slabs was discovered, containing figurines of the Tanagra class, and black glaze pottery of $4^{\text {th }}$ and $3^{\text {rd }}$ century types. A pyxis was found on top of one of these graves containing the cosmetic mentioned by Xenophon in the Oeconomicus for producing the opposite effect to that of rouge.

\section{NEWS AND COMMENTS}

A CORRESPONDENT writes to point out that the Italian edition of Prof. Mosso's book on Crete, reviewed last month, costs only 6s. $6 \mathrm{~d}$. (8 lire), unbound. It contains the same illustrations, but not so much letterpress. Some may like to buy it for the illustrations, as a companion to Prof. Burrows's book.

We wish also to call attention to a new edition of Prof. W. Rhys Roberts's Longinus on the Sublime (Camb. Univ. Press), which by some oversight has not been mentioned before. There must be a renewed interest in that admirable book of criticism, for which Prof. Roberts's edition is largely responsible.

The Proceedings of the Classical Association of Scotland (1907-8) are before us. They contain the records of two meetings, including two Presidents' Addresses, a paper on 'Unseen Translation as a Teaching Instrument' (Prof. Phillimore), with debate; one on the 'Religious and Moral Ideas of Euripides' (Prof. Burnet); and one on the
'Relation of Archaeology to Classical Studies' (Prof. Ridgeway).

Prof. Brown describes the state of Classical Education in New Zealand. We learn that Greek is practically dead in New Zealand schools : a useful commentary on the arguments for abolishing compulsory Greek in its own interests. Prof. Brown criticises the results of Latin teaching in England, and attributes the general failure to narrow reading and the disuse of speech. He points out that satisfactory work in New Zealand is impossible with the present system of examination; and it appears that the Universities are actually examined from England.

Prof. Phillimore argues eloquently for enlarged scope of reading, and suggests the systematic use of the Unseen, not as a trap for the unwary, but as giving specimens of different ages, styles, and subjects. $\mathrm{He}$ also had a word to say of examinations as the enemy of the teacher. It is surely time that the matter of examinations should be seriously taken in hand. 